\title{
AC 2008-1078: DEVELOPMENT OF AN INSTRUMENT TO COLLECT PEDAGOGICAL DATA FROM GRADUATE TEACHING ASSISTANTS WITHIN ENGINEERING LABORATORIES
}

Nathan McNeill, Purdue University

Monica Cox, Purdue University

Heidi Diefes-Dux, Purdue University

Tenille Medley, Purdue University

Jeremi Hayes, Purdue University 


\title{
Development of an Instrument to Collect Pedagogical Data from Graduate Teaching Assistants within Engineering Laboratories
}

\begin{abstract}
Most graduate teaching assistants receive little or no pedagogical feedback on their instruction. This paper describes the first steps in the development of instruments to provide pedagogical feedback to engineering laboratory graduate teaching assistants. The project began with use of the VaNTH Observation System, a direct observation instrument which provides feedback about the extent to which an instructor's interactions with students fit within the dimensions of the "How People Learn" framework, a model of effective teaching and learning as presented in the National Research Council monograph, How People Learn: Brain, Mind, Experience, and School. Preliminary findings revealed challenges to the use of this instrument in a first-year engineering laboratory course taught by graduate teaching assistants. To provide information for the adaptation of this instrument for use in the laboratory environment and to aid in developing new instruments, the graduate teaching assistants in this course were surveyed to determine their roles and assess the extent to which they employed a set of nineteen specific pedagogical activities representing good pedagogical techniques according to the "How People Learn" framework.
\end{abstract}

\section{Background}

Several studies have noted that graduate teaching assistants receive little or no pedagogical feedback on their instruction ${ }^{1-4}$. Torvi, in his 1994 study of thirteen engineering schools, found that only $45 \%$ of the engineering departments at these institutions had "some formal performance evaluation procedure" for graduate teaching assistants ${ }^{4}$. Luft et al. point out that the lack of feedback leads graduate teaching assistants to "make intuitive decisions, or decisions based on their own experience as students" resulting in teaching practices which are "often disconnected from the literature base in education."1 The National Science Foundation funded project described in this paper seeks to develop theoretically-grounded instruments that provide pedagogical feedback to graduate teaching assistants about the quality of their instruction.

This project began with the testing of a modified portion of the VaNTH Observation System (VOS) ${ }^{5-11}$. The VaNTH Engineering Research Center (an acronym based on the names of the member institutions: Vanderbilt University, Northwestern University, University of Texas at Austin, and the Harvard/Massachusetts Institute of Technology Division of Health Science and Technology) developed the VOS in 1999 for use in observing the pedagogy employed by instructors in bioengineering classrooms. The VOS provides feedback based on the "How People Learn" framework, a model of effective learning and teaching as presented in the National Research Council monograph, How People Learn: Brain, Mind, Experience, and School ${ }^{12}$. The "How People Learn" framework is composed of four dimensions which should all be present in an effective learning environment. These dimensions are knowledge-centeredness, learnercenteredness, assessment-centeredness, and community-centeredness. 
With the VOS, observers use a piece of software running on a handheld computer to collect observational data. Several different types of data are collected at regular intervals throughout the duration of a class period. In this project, only the Classroom Interaction Observation (or CIO) portion of the VOS has been used. With the CIO, five types of data are to be collected at 6 second intervals ${ }^{10}$. Testing of the CIO in a first-year engineering laboratory course throughout the duration a semester revealed a number of short-comings. Trained observers found that they could record data at no better than 15 second intervals due to the complexity of interactions in the laboratory. Unlike traditional lecture course environments, the observed laboratory classes involved nearly continuous exchanges between graduate teaching assistants and groups of students with interactions often occurring at intervals of less than 1 second. At this pace, a significant portion of interactions were not recorded by the observers. The VOS was also found to produce feedback that was difficult for graduate teaching assistants who are untrained in pedagogical theory to understand. As a first step in developing an instrument to provide more descriptive feedback to graduate teaching assistants, a survey was conducted to explore the extent to which a set of activities representing good pedagogical techniques according to the "How People Learn" framework were being employed by the graduate teaching assistants in this course. The survey also asked the graduate teaching assistants to list the roles they assume as instructors for this course. The research questions for this study are:

Research Question 1: To what extent are a set of pedagogical techniques based on multiple dimensions of the "How People Learn" framework present in the instruction of a group of engineering graduate teaching assistants?

Research Question 2: What roles do these engineering graduate teaching assistants assume?

\section{Methods}

The participants in this study were the graduate teaching assistants for a first-year engineering course required of all engineering majors at Purdue University. This course involves two weekly lectures taught by a faculty member and a two-hour weekly laboratory session lead by a graduate teaching assistant. This study was conducted during the Fall semester of 2007. The enrollment during this semester was greater than 1500 with 19 graduate teaching assistants leading 54 laboratory sections. Each graduate teaching assistant is assisted by an undergraduate teaching assistant and teaches two or three laboratory sections per week with about 30 students in each section. The students meet in computer labs where they learn to use software tools such as MATLAB and EXCEL to solve engineering design problems.

A survey was created to evaluate how often graduate teaching assistants were employing specific pedagogical activities each representing multiple "How People Learn" dimensions. This survey was an adaptation of the "Experiences in and Benefits from this Course" instrument that was used to assess the effects of the VaNTH Engineering Research Center ${ }^{13}$. The survey in this study consisted of twenty items. The first nineteen items described specific pedagogical activities and asked participants to indicate two things:

1. How often they had the opportunity to engage in each activity during the semester.

2. How often they actually engaged in each activity. 
These two separate ratings allowed for a determination of activities for which there is room for improvement. For each item, the participants were given three options for rating the frequency of occurrence: Never, A few times per semester, and During every lab period. Participants were given a space after each question in which to write comments. The final item on the survey was an open-ended question which asked participants to describe their roles as graduate teaching assistants. The survey was piloted with two graduate students who are former graduate teaching assistants for the same first-year engineering course taught by the participants in this study.

Observational notes were collected by two observers from 18 laboratory sessions throughout the semester. These notes described the tasks that the students worked on and the activities that the graduate teaching assistants were engaged in. One of the observers also took notes at a weekly meeting that the graduate teaching assistants had with the laboratory supervisor.

\section{Results and Discussion}

Twelve of the nineteen graduate teaching assistants returned the survey for a response rate of $63 \%$. Results from the first nineteen survey items were scored on a scale from 0 to 2 . A score of 0 was assigned to responses for "Never", 1 for responses of "A few times per semester", and 2 for responses of "During every lab period". Table 1 shows the average score from the twelve respondents for each item as well as the standard deviation for each item. The observational notes and notes from the weekly meetings with the laboratory supervisor were used to support explanations for some of the resulting scores.

The scores for items 1, 4, and 6 indicate that these activities can and do occur in nearly every lab session as the average scores were relatively high (greater than 1.5). The graduate teaching assistants were required to administer a short quiz at the end of nearly every laboratory period, so it is no surprise that item 4 ("Provide opportunities during class that help students check how well they understand the material") received a relatively high score. Items 1 and 6 ("Find ways to help students answer their own questions" and "Tailor your interactions so that they match the abilities or aptitudes of the students") are activities that the graduate students were encouraged to engage in by the laboratory supervisor during at least one weekly meeting. Two of the survey respondents were also enrolled in a pedagogical training course which encouraged these activities.

The score for item 3 ("Ask students to help each other understand ideas or concepts") was greater than 1.5 for having occasion to do the activity while the score for actually doing the activity was less than 1.5. Although the activity described in item 3 is similar to item 1 , and its score for having occasion to do the activity was also similar, it scored lower for actually doing the activity. A possible explanation for this difference in scores may be that graduate teaching assistants do not trust students to adequately answer each others' questions and consequently do not engage in this activity as often as they could. 
Table 1. Responses to the first nineteen survey items.

\begin{tabular}{|c|c|c|c|c|c|}
\hline \multirow{2}{*}{\multicolumn{2}{|c|}{ Items }} & \multicolumn{2}{|c|}{$\begin{array}{c}\text { How often do } \\
\text { respondents } \\
\text { have occasion } \\
\text { to... }\end{array}$} & \multicolumn{2}{|c|}{$\begin{array}{c}\text { How often do } \\
\text { respondents } \\
\text { actually... }\end{array}$} \\
\hline & & 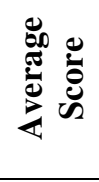 & 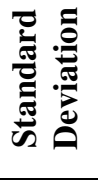 & 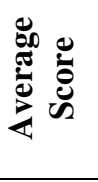 & 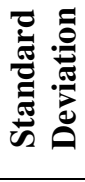 \\
\hline 1 & Find ways to help students answer their own questions & 1.8 & 0.5 & 1.8 & 0.5 \\
\hline 2 & Relate course material to real life situations & 1.0 & 0.0 & 1.0 & 0.0 \\
\hline 3 & $\begin{array}{l}\text { Ask students to help each other understand ideas or } \\
\text { concepts }\end{array}$ & 1.9 & 0.3 & 1.4 & 0.7 \\
\hline 4 & $\begin{array}{l}\text { Provide opportunities during class that help students } \\
\text { check how well they understand the material }\end{array}$ & 1.7 & 0.5 & 1.6 & 0.5 \\
\hline 5 & $\begin{array}{l}\text { Obtain information at the end of class on what students } \\
\text { have learned that day }\end{array}$ & 1.1 & 0.8 & 0.8 & 0.7 \\
\hline 6 & $\begin{array}{l}\text { Tailor your interactions so that they match the abilities } \\
\text { or aptitudes of the students }\end{array}$ & 1.6 & 0.5 & 1.5 & 0.5 \\
\hline 7 & $\begin{array}{l}\text { Stimulate students to intellectual effort beyond that } \\
\text { required by most courses }\end{array}$ & 1.1 & 0.7 & 0.9 & 0.7 \\
\hline 8 & $\begin{array}{l}\text { Ask students to explain the basis for their answers to } \\
\text { questions }\end{array}$ & 1.4 & 0.7 & 1.3 & 0.7 \\
\hline 9 & $\begin{array}{l}\text { Assess what students already know before presenting } \\
\text { new material }\end{array}$ & 1.3 & 0.8 & 1.0 & 0.7 \\
\hline 10 & $\begin{array}{l}\text { Assess students' preconceptions about a topic before } \\
\text { presenting new material }\end{array}$ & 0.8 & 0.7 & 0.4 & 0.5 \\
\hline 11 & $\begin{array}{l}\text { Encourage students to use multiple resources to improve } \\
\text { their understanding }\end{array}$ & 1.2 & 0.7 & 0.8 & 0.6 \\
\hline 12 & $\begin{array}{l}\text { Use feedback from the students to improve your } \\
\text { instruction }\end{array}$ & 1.2 & 0.8 & 1.1 & 0.9 \\
\hline 13 & $\begin{array}{l}\text { Create an environment in which creative thinking and } \\
\text { expression are encouraged }\end{array}$ & 1.2 & 0.6 & 1.1 & 0.5 \\
\hline 14 & $\begin{array}{l}\text { Ask students to share ideas and experiences with others } \\
\text { whose backgrounds and viewpoints differ from their } \\
\text { own }\end{array}$ & 1.2 & 0.7 & 0.9 & 0.8 \\
\hline 15 & Tailor your instruction to match the goals of the students & 1.1 & 0.8 & 0.9 & 0.7 \\
\hline 16 & $\begin{array}{l}\text { Ask students to make predictions about different } \\
\text { situations that illustrate class topics }\end{array}$ & 0.9 & 0.8 & 0.5 & 0.7 \\
\hline 17 & $\begin{array}{l}\text { Obtain information on which concepts need more } \\
\text { clarification }\end{array}$ & 1.4 & 0.7 & 1.4 & 0.7 \\
\hline 18 & $\begin{array}{l}\text { Inspire students to set and achieve goals that are } \\
\text { challenging }\end{array}$ & 1.0 & 0.9 & 0.8 & 0.7 \\
\hline & Form teams or groups to facilitate learning & 1.5 & 0.5 & 1.4 & 0.5 \\
\hline
\end{tabular}


Items 5 and 19 ("Obtain information at the end of class on what students have learned that day" and "Form teams or groups to facilitate learning") may have been confusing for the participants as these activities are imposed by the laboratory supervisor and are not necessarily engaged in by the graduate teaching assistants of their own volition. As previously mentioned, nearly every lab session concluded with a quiz that the graduate teaching assistants were required to administer. Also, during nearly every lab period the graduate teaching assistants were instructed by the laboratory supervisor to have their students work on the laboratory tasks in teams. Participants may have been uncertain whether to report such activities because they were imposed and not voluntary.

Items $2,10,16$, and 18 had scores of 1.0 or less for both having the occasion to do the activity and actually doing the activity. This indicates that these activities occur very rarely during the semester. Many graduate teaching assistants may not have the experience to be able to engage in item 2 ("Relate course material to real life situations"). The purpose of the laboratory sessions was not to present new material but to give students a chance to apply concepts which they learned during a separate lecture portion of the course. As a result, many participants may not have viewed item 10 ("Assess students' preconceptions about a topic before presenting new material") as relevant because the presentation of new material was not a part of their required duties as a graduate teaching assistant for this course. Interestingly, item 9 ("Assess what students already know before presenting new material") did not have as low a score even though it is about the presentation of new material. Each laboratory session had multiple tasks for the students to complete and quite often students were unable to complete the tasks within the laboratory time. As a result, both the students and graduate teaching assistants were focused on completing the required tasks. Consequently, the graduate teaching assistants may not have felt they had the time to engage in item 16 ("Ask students to make predictions about different situations that illustrate class topics"). The focus on completing the prescribed laboratory tasks may have meant that the graduate teaching assistants did not feel they had the time or freedom to help students set and achieve goals outside of the framework of the course as described by item 18 ("Inspire students to set and achieve goals that are challenging").

The final item on the survey asked participants to describe their role as a graduate teaching assistant for the first-year engineering laboratory course described in this study. Only nine of the twelve survey respondents chose to answer this question. Open-coding was used to analyze the responses to this item. The two most common roles that surfaced were "grading" and "facilitating". Several participants described grading using language which indicated that they disliked this activity because it took up a significant portion of their time. When speaking of facilitating, respondents described supporting the objectives of the department, making sure their students finished all of the required tasks for each laboratory session, proctoring quizzes and exams, and even such mundane tasks as handing out papers. Other roles that surfaced in the coding were "guiding" or "helping" students through the laboratory exercises, "teaching" or "lecturing", and "mentoring". Only two participants indicated that they took an active role in the development of the course curriculum through writing homework assignments or quizzes. 


\section{Conclusions and Future Work}

The responses to the first nineteen items on the survey answer the first research question by indicating that the majority of the pedagogical activities on the survey were relevant to the engineering laboratory course in this study. This survey provides only a "snapshot" of one particular type of laboratory course at one point in time. This limitation means that results cannot necessarily be generalized. This laboratory course has seen some significant curricular restructuring since this survey was administered. Future work will review changes to this course as well as examine the roles of graduate teaching assistants in other engineering courses. Direct observations of the items in the survey were undertaken by the study's observers at the end of the semester in an attempt to corroborate the findings of the survey. However, in order to make a valid comparison, data from across the entire semester are required.

The second research question asked what roles the graduate teaching assistants in this study assumed. The notes from the weekly meetings with the laboratory supervisor made it clear that the graduate teaching assistants in this study were not typically expected to present new material or concepts to the students in their laboratory sections. The graduate teaching assistants were also not involved in the process of developing the curriculum for the course. Instead, the graduate teaching assistants indicated in the survey that they act as facilitators making sure that each lab period ran smoothly and that the students accomplished the tasks that they were assigned. They indicated that they spent a considerable amount of time outside of the laboratory sessions grading students' assignments and that they helped guide students through the laboratory tasks and acted as mentors. These roles match the activities observed by Murphy et al. who developed a coding scheme for studying mentoring, coaching, and facilitating behavior in the interactions between participants in an online course ${ }^{14}$. Future work will involve mapping direct observations from the VOS with the coding scheme developed by Murphy et al. and adaptation of this coding scheme for direct observation in engineering laboratory courses.

\section{Acknowledgements}

We wish to thank the National Science Foundation for their funding of this work through grant number EEC-0648380 and Noemi Mendoza-Diaz and Rocio Chavela Guerra for their expertise and help in coding the survey responses.

\section{References}

[1] J. A. Luft, J. P. Kurdziel, G. H. Roehrig, and J. Turner, "Growing a Garden Without Water: Graduate Teaching Assistants in Introductory Science Laboratories at a Doctoral/Research University," Journal of Research in Science Teaching, vol. 41, pp. 211-233, 2004.

[2] E. Seymour, Partners in Innovation: Teaching Assistants in College Science Courses. Lanham, MD: Rowman \& Littlefield, 2005.

[3] D. M. Shannon, D. J. Twale, and M. S. Moore, "TA Teaching Effectiveness: The Impact of Training and Teaching Experience," Journal of Higher Education, vol. 69, pp. 440-466, 1998.

[4] D. A. Torvi, "Engineering Graduate Teaching Assistant Instructional Programs: Training Tomorrow's Faculty Members," Journal of Engineering Education, vol. 83, pp. 1-6, 1994.

[5] M. F. Cox and A. H. Harris, "The Significance and Limitations of the VaNTH Observation System Within Engineering Classrooms," in ASEE Annual Conference \& Exposition: Staying in Tune with Engineering Education, Nashville, TN, 2003. 
[6] M. F. Cox and A. H. Harris, "A Comparison of Bioengineering Faculty Members' Teaching Patterns at One Research University," in American Society for Engineering Education Annual Conference \& Exposition, 2004.

[7] M. F. Cox and A. H. Harris, "An Examination of Changes in Bioengineering Faculty Pedagogy Within "How People Learn" Environments"," in American Society for Engineering Education Annual Conference \& Exposition, 2005.

[8] M. F. Cox and A. H. Harris, "VaNTH Observation System Component Assessment," in American Society for Engineering Education Annual Conference \& Exposition, 2006.

[9] A. H. Harris, D. S. Cordray, and T. R. Harris, "Measuring What is Happening in Bionengineering Classrooms - An Observation System to Analyze Teaching in Traditional Versus Innovative Classrooms," in The Second Joint EMBS/BMES Conference, Houston, TX, 2002, pp. 2618-2619.

[10] A. H. Harris and M. F. Cox, "Developing an Observation System to Capture Instructional Differences in Engineering Classrooms," Journal of Engineering Educaiton, vol. 92, pp. 329-336, 2003.

[11] P. R. Norris, A. H. Harris, and C. W. Washington, "The VOS Data Manager: Providing Immediate Feedback on Teaching Effectiveness," in American Society for Engineering Education Annual Conference \& Exposition, 2004.

[12] J. D. Bransford, A. L. Brown, and R. R. Cocking, How People Learn: Brain, Mind, Experience, and School. Washington, D.C.: National Academy Press, 2000.

[13] D. S. Cordray, G. M. Pion, A. Harris, and P. Norris, "The Value of the VaNTH Engineering Research Center," IEEE Engineering in Medecine and Biology Magazine, vol. 22, pp. 47- 54, 2003.

[14] K. L. Murphy, S. E. Mahoney, C.-Y. Chen, N. V. Mendoza-Diaz, and X. Yang, "A Constructivist Model of Mentoring, Coaching, and Facilitating Online Discussions," Distance Education, vol. 26, pp. 341-366, 2005. 